Of Philip K. Dick, Reflexivity, and Shifting Realities:

Organising (Writing) in Our Post-Industrial Society

\author{
Christian De Cock \\ Department of Business and Management \\ School of Business and Economics \\ University of Exeter \\ Streatham Court \\ Rennes Drive \\ Exeter EX4 4PU \\ (c.de-cock@exeter.ac.uk)
}




\section{Of Philip K. Dick, Reflexivity, and Shifting Realities: \\ Organising (Writing) in Our Post-Industrial Society}

'Imaginations of the future, like imaginations of the past, are devices for living in the present (March, 1995, p.427).'

'I don't accept the judgement that in using images and metaphors of other worlds, space travel, the future, imagined technologies, societies, or beings, science fiction escapes from having human relevance to our lives. Those images and metaphors used by a serious writer are images and metaphors of our lives, legitimately novelistic, symbolic ways of saying what cannot otherwise be said about us, our being and our choices, here and now. What science fiction does is enlarge the here and now (LeGuin, 1994, p.5).’

'But are you writing something serious?' Note the word. Fuck. If they couldn't get us to write serious things, they solved the problem by decreeing that what we were writing was serious (Dick, 1978/1991, p.152 ${ }^{1}$ ).'

\section{PHILIP K. DICK, ORGANISATION STUDIES AND ME}

I have to admit I have some slight misgivings about writing an 'academic' chapter on Philip K. Dick. Not that I am the first to do so. In the 20 years or so since his death, Philip K. Dick has attracted a small army of interpreters. He has been seen as a prophet of hyperreality and as a gnostic visionary of the suburbs (Starr, 1993). In discussions on the internet he is often referred to as the 'Godfather of Cyberpunk' Certainly, Dick created a body of fiction that brings to life the indeterminacy between originals and simulacra that is the hallmark of virtual reality - both as metaphor and as technology - of post-industrial society (Sutin, 1995). Dick’s landscapes tend to be highly commercialised spaces in which the boundaries between autonomous individual and technological artefact have become increasingly permeable (Hayles, 1999). But more of this later. My misgivings have to do with the fact that Dick, a writer who spent most of his life working within the tight confines of the pulp markets, felt animosity toward 'mainstream' academicians who sought to adopt SF, as 
it were, and make it respectable or important (notwithstanding the fact that, at the same time, the lack of mainstream attention for his work was a source of pain for him). The following extract of an unpublished book review captures this animosity: 'If SF becomes annexed to the academic world it will buy into its own death... Professor Warrick's pound-and-a-half book with its expensive binding, paper, and dust jacket staggers you with its physical impression, but it has no soul and it will take our soul in what really seems to me to be brutal greed. Let us alone, Dr. Warrick; let us read our paperback novels with their peeled eyeball covers. Don't dignify us. Our power to stimulate human imagination and to delight is intrinsic to us already. Quite frankly, we were doing fine before you came along (Dick, 1980/1995, p. 97-98),

So why write this article? A healthy (?) obsession with Dick’s œvre I suppose, coupled with the comforting realisation that Dick contradicted himself so many times in his lifetime. But to truly answer this question I have to tell the brief story of Philip K. Dick, organisation studies, and me.

My introduction to the world of Philip K. Dick began in 1985 when I was given two Dick books - Ubik and Flow My Tears, the Policeman Said - as a birthday present. The girl in question was from Metz, a very Dickean connection as I found out later ${ }^{2}$, the books were written in French and published in flashy golden covers (as far as you can get from the peeled eyeball covers as possible). I remember reading them (my French was a lot better then than it is now), being pretty impressed with Ubik especially, and then filing the books away in my SF collection. Fast forward to 1992. This is the year I started my PhD studies. I came across the Rethinking Organization book by Reed and Hughes, and to my surprise two of my favourite chapters briefly referenced this SF author I vaguely remembered reading a few years earlier (Burrell, 1992, p.177; Turner, 1992, p.56). I then bought one of Dick’s short story collections (perhaps in the hope of using it for my PhD studies - I wisely didn't). And suddenly I was addicted. The next couple of years I tried to collect as many Dick books as possible, including the English editions of my birthday books. A moment I recall with particular fondness is finding a perfect copy of Now Wait for Last Year in a car boot sale for 10p. This sudden obsession was not uncommon as I discovered later: 
'In my role as editor of the Philip K. Dick Society Newsletter, I frequently get letters from people who just a few months ago discovered Dick's work and have now read fifteen books and must obtain all the others. He tends to be read as he wrote: in large doses (Williams, 1986, p.142).'

Then came the call for papers, first for the special SF issue of Organization in 1997, later for this book. This got me reading Dick's collected philosophical writings and his Exegesis, as well as some literary criticism of Dick's work. So, you see, the link between organisation studies and Philip K. Dick is self-evident to me. Of course, this still does not provide an answer to the question: 'How to write something meaningful?'

An academic book presupposes a particular style that does not necessarily do justice to the work of Dick (although Dick himself has written some pretty highbrow stuff). After some pondering I decided upon the following strategy. After introducing the problematic from the perspective of organisation studies - the growing awareness of the tenuous nature of organisational reality and the difficulty we have in constructing texts that deal with this tenuous reality in a reflexive way - I explore the key characteristics of Dick's novels and the essence of his writing techniques. This is followed by a discussion of Ubik to give the reader a flavour of a typical Dickean novel. I conclude with the logical, but rather too predictable, discussion of the importance of Dick for the field of organisation studies. Of course, it would be nonsensical to suggest that we can 'apply' Dick in the way it has happened with Foucault, Derrida or Elias, but to name a few. Yet there is be something curiously attractive about an author who used the most trashy tropes of a genre (SF) to create a body of work that both transcends and invigorates that genre. Could this point to an analogue in organisation theory that might enable us to frame new possibilities of writing or reading organisational narratives? Perhaps.

\section{MODES OF ORGANISING, MODES OF THEORISING AND THIS THING} CALLED REALITY

'As Marx might have said more generally, “all that is built or all that is 'natural' melts into image” in the contemporary global economies of signs and space (Lash \& Urry, 1994, p.326).' 
The opinion seems to be broadly shared among both academics and practitioners that traditional conceptions of effective organising and decision-making are no longer viable because we live in a time of irredeemable turbulence and ambiguity (Gergen, 1995). The emerging digital or 'new' economy seems to be a technologically driven vision of new forms of organizing, relying heavily on notions of flexibility as a response this turbulence. Corporate dinosaurs must be replaced with smart networks that add value. Words such as 'cyberspace' ${ }^{3}$ and 'cyborganisation' drip easily from tongues (e.g. Parker \& Cooper, 1998) and ‘the organisation’ becomes more difficult to conceptualise as it 'dissipates into cyberspace' and 'permeates its own boundaries' (Hardy and Clegg 1997: S6). Organisations are losing important elements of permanence as two central features of the modern organisation, namely the assumption of self-contained units and its structural solidity, are undermined (March, 1995). Even the concept of place becomes increasingly phantasmagoric as locales get thoroughly penetrated by social influences quite distant from them (Giddens, 1990).

In this new organisational world 'reality' seems to have become only a contract, the fabrication of a consensus that can be modified or can break down at any time (Kallinikos, 1997) and the witnessing point - the natural datum or physical reference point - seems to be in danger of being scrapped (Brown, 1997). This notion that reality is dissolving from the inside cannot but be related with feelings of disorientation and anxiety. Casey (1995, p.70-71), for example, provides a vivid description of the position of 'the self' within these new organisational realities. This is a world where everyone has lost a sense of everyday competence and is dependent upon experts, where people become dependent on corporate bureaucracy and mass culture to know what to do. The solidity (or absence of it) of reality has of course been debated at great length in the fields of philosophy and social theory, but it remains an interesting fact that organisational scholars have become preoccupied with this issue in recent years. Hassard and Holliday (1998), for example, talk about the theoretical imperative to explore the linkages between fact/fiction and illusion/reality. It is as if some fundamental metaphysical questions have finally descended into the metaphorical organisational street. 
Over the past decade or so, many academics who label themselves critical management theorists and/or postmodernists (for once, let's not name any names) have taken issue with traditional modes of organising (and ways of theorising about this organising) by highlighting many irrationalities and hidden power issues. These academics have taken on board the idea that language has a role in the constitution of reality and their work is marked by a questioning of the nature of reality, of our conception of knowledge, cognition, perception and observation (e.g. Chia, 1996a; Cooper \& Law, 1995, Czarniawska, 1997). Notwithstanding the importance of their contributions, these authors face the problem that in order to condemn a mode of organising or theorising they need to occupy an elevated position, a sort of God's eye view of the world; a position which they persuasively challenge when they deconstruct the claims of orthodox/modern organisational analyses (Parker, 2000; Weiskopf \& Willmott, 1997). Chia, for example, writes about the radically untidy, ill-adjusted character of the fields of actual experience - 'It is only by... giving ourselves over to the powers of 'chaos', ambiguity, and confusion that new and deeper insights and understanding can be attained (Chia, 1996b, p.423)' - using arguments which could not be more tidy, analytical and precise. This of course raises the issue of reflexivity: if reality can never be stabilised and the research/theorising process 'is always necessarily precarious, incomplete and fragmented' (Chia, 1996a, p.54), then Chia's writing clearly sits rather uncomfortably with his ontological and epistemological beliefs. In this he is, of course, not alone (see, e.g., Gephart et al., 1995; Cooper \& Law, 1995).

This schizophrenia is evidence of rather peculiar discursive rules where certain ontological and epistemological statements are allowed and even encouraged, but the reciprocate communicational practices are disallowed. Even the people who are most adventurous in their ideas or statements (such as Chia) are still caught within rather confined communicational practices. To use Vickers' (1995) terminology: there is a disjunction between the ways in which organisation theorists are ready to see and value the organisational world (their appreciative setting) and the ways in which they are ready to respond to it (their instrumental system). When we write about reflexivity, paradox and postmodernism in organisational analysis, it is expected that we do this unambiguously ${ }^{4}$. And yet, the notion that 'if not consistency, then chaos' 
is not admitted even by all logicians, and is rejected by many at the frontiers of natural science research - 'a contradiction causes only some hell to break loose' (McCloskey, 1994, p.166).

\section{COMING TO GRIPS WITH PHILIP K. DICK’S SHIFTING REALITIES}

'I am a fictionalizing philosopher, not a novelist; my novel \& story-writing ability is employed as a means to formulate my perception... I think I understand the common ingredient in those whom my writing helps: they cannot or will not blunt their own intimations about the irrational, mysterious nature of reality, \&, for them, my corpus of writing is one long ratiocination regarding this inexplicable reality, an investigation \& presentation, analysis \& response \& personal history (Dick 1978/1991, p.161).’

'There is no worse mistake than taking the real for the real... (Baudrillard, 1994, p.61)'

The increasing awareness of the tenuous nature of (organisational) reality and the difficulty organisational scholars experience in constructing texts that deal with this tenuous reality in a reflexive way creates a space to reflect on the work of Philip K. Dick. Dick fully accepts that the late modern condition attendant on the everexpanding proliferation of realities cannot be undone or overcome (i.e. going back to one reality which replaces values with facts) but has to be faced, tolerated, and worked through. In book after book, Dick portrays an elemental estrangement of reality. Dickian characters find themselves trapped in hallucinations or fake worlds of various kinds, often without knowing it or, if knowing it, without being able to do anything about it. And it is not only worlds that are fake. Objects, animals, people may also be unreal in various ways (Aldiss, 1979). There can be no longer any talk of returning to nature or of turning away from the 'artificial', since the fusion of the natural with the artificial has long since become an accomplished fact (Lem, 1984). As Dick himself suggested in a reflective essay:

'What we are seeing is a gradual merging of the general nature of human activity and function into the activity and function of what we humans have built and surrounded ourselves with... As the external world becomes more animate, we may find that we the so-called humans - are becoming, and may to a great extent always have been, 
inanimate in the sense that we are led, directed by built-in tropisms, rather than leading (Dick, 1972/1995, p.183-187).'

Up to the late 1950s Dick could be characterised as a writer of mainly anti-utopian SF. From then onwards he developed a penchant for plots that emphasised metaphysical speculations without providing any moral or ontological solutions (Sutin, 1995). Not surprisingly, he was initially considered something of an odd figure by the SF community (Sutin, 1991). The convention of SF in the 1950s and 1960s required rational accounting for events that were quite improbable and even seemingly at odds with logic and experience. Thus, although SF stories depicted an imaginary reality, their authors were often at pain to create characters who embodied familiar values, outlooks, and mannerisms. For example, John W. Campbell's magazine Astounding Stories insisted that writers postulate one outlandish circumstance - the 'what if?' clause - and rigorously follow the laws of science from there (Starr, 1993). Authors such as Asimov, Heinlein and Bradbury, remained faithful to these requirements of scientific accuracy and plausible prophecy. Not so Dick.

What Dick offers is not so much the future foreseen, as future shock, a projection of the fears and fascinations proper to the human individual in our times. The plots of most of his SF novels are moved from page to page by doubt and by the collapse of the characters' and author's assumptions as to what is going on, forcing new hypotheses and new plot developments. Dick's characters generally begin as naive realists, firmly convinced that their perceptions provide them with knowledge about what is actually present in the world around them. But then they are usually thrown into an encounter where both external reality and their own identities are drastically questioned. As Dick forces his characters to confront these questions, he portrays the basic dilemma of our post-industrial society: we can no longer tell the illusory from the substantial; we no longer have an absolute basis for knowing what is real or what is human. For Dick, 'the clear line between hallucination and reality has itself become a kind of hallucination' (Warrick, 1983, p.205). Dick’s inability to experience the solidity of any one reality becomes fertile soil for the creation of endless alternate realities, each at last as convincing as the one that went before and 
each containing some primal error, something 'out of joint', and the location of that error can never be decided upon. Everything may be dissolved, invaded and subtly infiltrated or discovered to be a fabrication. In stories like Breakfast at Twilight and The Hanging Stranger, what is truly chilling is not that the ordinary human person and environment can be manipulated into inhumanity or into naturalising evil conditions as normal, but that the ordinary human person and environment is not substantially 'there' to be manipulated (Palmer, 1995).

Any analytic discussion of Dick’s work makes it sound to be grim and unappealing. On the surface, it may be; yet it must also be said that Dick is often amazingly funny. As his characters confront exasperating hallucinations and intersecting timesequences, they respond with a typical blend of desperate speculation, cautious empathy and brittle humour (Starr, 1993). The terror and the humour are fused. It is in this rare quality that Dick's work resembles Kafka's, producing a 'Ghastly Comedy of bafflement' (Aldiss, 1979, p.58).

\section{ON DICK'S WRITING TECHNIQUES: THE WRITING THAT CANNOT BE WRITTEN}

'And this is how it is: if only you do not try to utter what is unutterable then nothing gets lost. But the unutterable will be - unutterably - contained in what has been uttered! (Wittgenstein ${ }^{5}$ )'

'All languages of heteroglossia, whatever the principle underlying them and making each unique, are specific points of view on the world, forms for conceptualising the world in words, specific world views, each characterised by its own objects, meanings and values. As such they all may be juxtaposed to one another, mutually supplement one another, contradict one another and co-exist in the consciousness of real people... They may all be drawn in by the novelist for the orchestration of his themes and for the refracted (indirect) expression of his intentions and values (Bakhtin, 1981, p.292).'

'I certainly see the randomness in my work, \& I also see how this fast shuffle of possibility after possibility might eventually, given enough time, juxtapose $\&$ disclose 
something important, automatically overlooked in more orderly thinking.... Since nothing, absolutely nothing, is excluded (as not worth being included) I proffer a vast mixed bag - out of it I shake coin operated doors \& God. It's a fucking circus. I'm like a sharp eyed crow, spying anything that twinkles \& grabbing it up to add to my heap (Dick, 1978/1991, p.147).’

The way Dick expresses his philosophical ideas is unusual, to say the least. His maddeningly profuse plots make a mockery of traditional criteria of 'good' writing. The plots may limp or soar, but they seldom hang together. To keep all the loose ends tied up would violate verisimilitude in the service of consistency, for the Dickian universe has ambiguity and indeterminacy at its core. Put simply, Dick writes about an untidy world in an untidy way, thus sacrificing consistency at the immediate level of plot developments or even a single novel, for meta-consistency when we come to consider his œvre in its totality. This provides an interesting way of 'working through' the reflexivity struggle in organisational analysis, without necessarily pointing to any clear solutions. Dick effortlessly incorporates in his stories the values of pluralism and fragmentation and an ironic admission of the ephemerality of things, values which attracted many organisational scholars to postmodernism (Kilduff \& Mehra, 1997).

Dick’s narrative polyphony approximates the heteroglossia Bakhtin (1981) had in mind. Dick’s novels are not exclusively human centred. They include other beings, other aspects of being. They may deal with relationships between people but may also explore the relationship between a person and something else: an android, a machine, a society. In Dick's fictions a creature that resembles a pudding or an insect may qualify as human even when something that looks, walks and talks like a man does not. But the acknowledgement of 'The Other' goes even further than that. A novel by Dick is not bound - and often is not - to be understood, because of its peculiar maximum span of meanings and because Dick never ridicules trash. In a Dickian universe, there are many realities, most of them equally valid, but none of them an overview of the whole. At any given moment, a character may gather the focus of attention around her; but the immediate reality is apt to dissolve into an equally valid alternate reality in which she/he/it has no significance whatsoever. A 
pluralous sense of meaning emerges as characters exchange views and interactively direct the storyline. This allows the reader to emphasise into all the focal characters, be they villains or heroes, for Dick has no black and white villains and heroes. In Dick’s collective, non-individualist world everybody, high and low, destroyer and sufferer, is in an existential situation which largely determines his/her actions; even the arch-destroyer Palmer Eldritch is a sufferer (Suvin, 1983).

Perhaps no better visual images catch the essence of a Dickian narrative structure than Chinese calligraphy, where a configuration of curved and straight lines forms a network. All parts are connected to all other parts, but not directly. By linear threads or veins, one can zigzag a way through the plot, but one is not given the hub of a central narrative view (Warrick, 1983). This is not to say that Dick's writing is 'clever' in the traditional technical sense. His novels are easy to read and sometimes verge on the clumsy. As Disch (1983, p.14) sympathetically commented:

'[Dick is] capable of whole chapters of turgid prose and of bloopers so grandiose you may wonder, momentarily, whether they're not just his little way of winking at his fellow laborers in the pulps.'

Dick employs glaring clichés of trash (e.g. the usual SF props of precognition, time travel, androids,...) to tackle exceedingly complex philosophical problems. This trashy surface allows his novels to survive in different ways in the reader's environment, either semiotically (awareness of the resurrection of metaphysical values) or semantically (very entertaining, if a bit disjointed) understood. Thus the novels contain some sort of double encoding which Lem (1984, p.85-86) explained as follows:

'If many coloured flags are put upon the masts of a ship in the harbour, a child on the shore will think that this is a merry game and perhaps will have a lot of fun watching, although at the same time an adult will recognize the flags as a language of signals, and know that it stands for a report on a plague that has broken out on board the ship.'

Of course this makes judgement work very difficult. What constitutes a good Dickean story? Dick, even by his own admission ${ }^{6}$, certainly produced a lot of very mediocre stories and novels, but in his best novels (e.g. Ubik, Martian Time Slip, The 
Three Stigmata of Palmer Eldritch) he creates something very special indeed. To quote Lem (1984, p.74) again:

'Dick has invented an extremely refined tactic: he uses elements of trash... so that he leads to a gradual resurrection of the long-extinct, metaphysical-exotic values. In a way he makes trash battle against trash... Dick succeeds in changing a circus tent into a temple, and during this process the reader may experience catharsis. It is extremely difficult to grasp analytically the means that make it possible for him to do so.' What is inconsistency in literature after all? It is a symptom either of incompetence or else of repudiation of some values (such as credibility of incidents or their logical coherence) for the sake of other values. There is no universally valid answer to the question whether it is permissible to sacrifice order for the sake of vision in a creative work, everything depends on what kind of order and what kind of vision are involved. Disorienting as Dick's narrative technique may be, it is essential if his project of imperfection is to be credible. His images are opposed to all that it is finished and polished and are ultimately expendable in his impossible quest for 'the writing that cannot be written':

'The greatest incentive to write is that you can't figure out the universe. And you keep trying to do it by writing about it. You can coerce it into making sense by writing a book that makes sense, but what happens is, your books don’t make any sense either (Interview with Dick, Williams, 1986, p.98).’

This impossible contradiction of 'the writing that cannot be written' forces a recognition of challenge, subversion because standard language or interpretative tools or intellectual categories are being jammed by the dissonance - the subaltern voice in the work itself (cf. Bernard-Donals, 1998, on Bakhtin’s work). The impossibility of imposing consistency on the text compels us to seek its global meanings not in the realm of events themselves, but in that of their constructive principle, the very thing that is responsible for lack of focus. For Dick there is a mysterious chaotic quality in the universe which is not to be feared. His best novels embody this inexplicable quality and thus defy analysis (Bishop, 1983).

'Ultimately, one intuits rather than analyzes Dick's meaning. The totality of his complex fictional gestalt cannot be grasped by a mere part-by-part discussion. We must temper our analysis with a more or less intuitive groping if we are to find our way to the power and insight of the fiction (Warrick, 1983, p.196).' 
One of the attractions of Dick's novels - and the most probable reason for my collection fever - is that they all have points at which they interrelate. The consensus among critics (Aldiss, 1979; Bishop, 1983; Warrick, 1983, Lem, 1984) seems to be that his books overlap and have a cumulative impact that is very different from what can be found and pointed to in any individual Dick novel. But that is quite enough analysis; time for the promised introduction to Ubik.

\section{UBIK}

Since Ubik was the first of Dick’s books I ever read, it is only appropriate that I use this novel to give the reader a flavour of Dick's shifting realities. Dick offers us here some kind of a Pirandelloesque ontology, where characters search not only for their author but also for their world. Like so many of Dick's novels, Ubik centres on the 'reality problem'. Information spontaneously intrudes into the world of the characters, indicating that their world is not what they think it is; in fact, it indicates that their world is not even there at all - some kind of world is there, but not the one they are experiencing. The characters never stop trying to make sense of a reality that grows progressively harder to grasp, but their efforts are always doomed to failure. Hollis lures Runciter, Joe Chip, and a staff of inertials (gifted psychics who can neutralise the psychic talents of others) to a death trap on Luna, and the resultant explosion casts them into a radically transformed reality that may or may not be controlled by Pat Conley or Runciter or Hollis or someone or something else. It's never quite clear who survived (if anyone) and who lies hallucinating in cold pac. The characters engage in a battle not only for their lives, but also to save the basic categories of existence as they are trying to make headway through a world that is becoming ever more primitive ${ }^{7}$. Every time they/we think they/we can make some sense of the situation, the plot takes a turn that leaves them/us utterly bewildered. Needless to say that neither the characters nor the readers are able to discover any final, comprehensive meaning.

The world of Ubik is thoroughly saturated by commodities that foreground their status as quasi-living signifiers. Not only do doors threaten to sue and coffee pots demand money for services rendered; telephone and TV sets occasionally adopt a will of their own and, much to human characters' confusion, transmit their messages in a way only 
very dubiously related to any human agency. A crass materialism has supplanted spiritual resilience as our chief 'reality support' and Ubik seems to signify all manner of capitalist predation. An epigraph in the form of an advertising jingle opens each chapter. These commercials which have nothing to do with the narrative sell Ubik as the best beer, the best instant coffee, etc. Ubik first appears in the narrative when Joe Chip finds himself watching a television commercial and listening to a 'hard eyed housewife' extolling its virtues: 'I came over to Ubik after trying weak, out of date reality supports'. The meaning of Ubik is mysteriously changed when in the final epigraph we find the following proclamation, creating a strange juxtaposition of religion with capitalist consumerism:

'I am the word and my name is never spoken, the name which no one knows. I am called Ubik, but that is not my name. I am. I shall always be.'

The novel provides no clues as to why Ubik changes from signifying the worst excesses of capitalism to standing for a ubiquitous God. The final reference to Ubik in the narrative is an ironic comment on divine intervention: after the attractive young woman, who has materialised from the future to bring Joe Chip a spray can of Ubik, disappears, leaving him in the middle of trying to invite her to dinner, he discovers a message on the can:

'I THINK HER NAME IS MYRA LANGLEY. LOOK ON REVERSE OF SIDE OF CONTAINER FOR ADDRESS AND PHONE NUMBER.’

\section{DICK AND THE DISCURSIVE UNIVERSE OF ORGANISATION STUDIES}

'It is precisely the fleeting, relationally responsive events that our current referentialrepresentational forms of rationality render invisible to us, and exclude from both rational discussion and attention. It is the urge towards both mastery and control implicit in all our current methodologies that leads us to banish particularised perceptions by ordering them into comprehensible and meaningful regularities (Shotter \& Billig, 1998, p.27).’

'I felt that the universe was so constructed that I could never really naturally follow the directions on anything and arrive easily and without effort at the right end. I think this is a learning thing, that the instructions that are easy for normal children are 
difficult for some children; they perceive a little differently, so that the ordinary instructions like 'color all the ducks yellow' somehow confuses some children for some perceptual reason (Dick interview in Williams, 1986, p.156).'

Up until a few years ago it would have been hard to imagine what role Dick's work could have played in the area of organisation studies. However, recent developments, such as the turn towards the humanities (Zald, 1996), the popularisation of postmodern discourse (Boje et. al, 1996; Kilduff \& Mehra, 1997) and the interest in narrative fiction (Easton \& Araujo, 1997; Phillips, 1995), make Dick’s work meaningful or at least plausible within an organisational context, although it certainly maintains a defamiliarisation value. Now that we are encouraged to view organising as an 'active and dynamic process of identity-construction and reality-configuration and, therefore, an ontological activity (Chia, 1997, p.699)', Dick’s preoccupations with the 'reality problem' have acquired a new relevance and urgency and may help us come to terms with the chimerical components of our existence. At the very least, an appreciation of Dick's work may open up a new arenas of intertextuality, pointing to new ways of seeing organisational processes and talking/writing about them.

Of course we will never be able to simply 'apply' Dick. His approach is the pure antithesis of the analytical framework. Do not turn to him for coherence or certainty. Dick sees any theoretical formulation that attempts to act as an all-encompassing, allexplaining hypothesis as a manifestation of paranoia (Easterbrook, 1995). We should be content with the mysterious, the meaningless, the contradictory. Emphasis in his stories is often on the gesture, the single action which may possibly be clever and moral enough for its insertion into the whole situation to, as it were, catch the whole situation off guard and make a difference (Dick, 1972/1995). But if this is a weakness, it is also a source of strength. Notwithstanding the increasing ontological and epistemological sophistication in organisation studies, the field still values simplification and systematisation which translates in the demand for structured and precise explanations. Although it has become more accepted to perceive social reality 'not as natural, rational, and self-evident but as arbitrary, and exotic' (Alvesson, 1996, p.111), acting upon that perception has remained as hard as ever. The field of organisation studies is still haunted by formulae (see, e.g., Locke \& 
Golden-Biddle, 1997; Golden-Biddle \& Locke, 1993). There is much to be said for formulae. They fulfil expectations and make the whole academic performance easier for writer, reviewer, editor and reader (cf. Aldiss, 1979), but they also bring selfimposed limits to our areas of inquiry and perhaps, more importantly, in their emphasis on analytical clarity they function more as obscuring than revealing devices (Bourdieu, 1992; Burrell, 1996). As Clegg and Hardy (1996, p.694) suggested: 'Analysis requires the death or at least the mutilation of that which is analysed. As researchers develop their understanding, they seem to become further removed from the subjects, less able to engage in conversation with them.'

Dick's writing may provide an antidote for the self-imposed and pre-established limits organisational scholars still suffer from. I indicated throughout this chapter that it is very difficult to grasp analytically what makes Dick's stories so compulsive to read or why he is considered to be 'one of the greatest experimental writers of our time (Baudrillard, 1991, p.312)'. Perhaps we should not even try. Only when texts are infinitely equivocal, forever supplementing their original message with noise supplied by the reader, do they remain saved from being consigned to obsolescence. I therefore very much like the description of the 'destructive drug-fuelled lunatic and 5cents-a-word hack ${ }^{8}$ one of the editors suggested. It is this aspect of Dick that is in danger of getting lost in any 'academic' analysis of his work. Dick never set out to rewrite the rules of the SF genre - he remained faithful to its most trashy tropes - and yet he managed to create a body of work that scarcely fits within the genre. I am not sure what form an analogue in organisation studies might take, but it would surely not be subject to the charge of "self-referential intellectualism" critical management studies have suffered from (Fournier \& Grey, 2000). Rather than taking the 'high road' of reifying managers as some kind of 'barbarian elite’ (cf. Anthony, 1998), and denouncing modernist epistemologies while still applying (and demanding) rational and sequential argument, we might want to take the 'low road' of full engagement with the trashier tropes of our particular genre (as found, for example, in newspaper and magazine articles, and television programmes exploring/exploiting happenings in the organisational sphere). Could we use some of the glaring clichés typifying the discourses of 'e-business' and 'virtual organisations' to tackle fundamental organisational issues, turning the circus into a temple as it were? This might require a 
mix of 'investigation \& presentation, analysis \& response \& personal history (Dick 1978/1991, p.161).' Perhaps we should break with the implicit rule of our field, the analogue of Campbell's 'what if?' clause, that we have to explain organisational phenomena all the time ${ }^{9}$, and foster instead the evocative ability which made Dick's utopias so startling and terrifying $^{10}$. Thus, rather than try and persuade readers, we would try to move and thrill them. The difficulty in developing such approaches is illustrated by the fact that this chapter sticks pretty much to the tried-and-trusted academic formulae, although it does contain a small personal history. Ultimately, it is only fitting - dare I suggest Dickean - to provide no real conclusion and let Philip K. Dick provide the last reflection on Philip K. Dick.

'This little section appears ahead of the text of the novel [The Three Stigmata of Palmer Eldritch]. It is the novel actually... Seventy-five thousand words, which I labored over many months... is merely there to provide background to the one small statement in the book that matters... It goes as follows, and this is all I actually have to say or want ever to say:

I mean, after all; you have to consider, we're only made of dust. That's admittedly not much to go on and we shouldn't forget that. But even considering, I mean it's a sort of bad beginning, we're not doing too bad. So I personally have faith that even in this lousy situation we're faced with we can make it. You get me? (Dick, 1972/1995, p.206) 


\section{REFERENCES}

Aldiss, B.W. (1979). This World and Nearer Ones: Essays Exploring the Familiar. London: Weidenfeld and Nicholson.

Anthony, P. (1998). Management Education: Ethics versus Morality. In M. Parker (Ed.), Ethics \& Organizations (pp. 269-281). London: Sage.

Astley, W. G., \& Zammuto, R. F. (1992). Organization Science, Managers, and Language Games. Organization Science, $\underline{3}(4), 443-460$.

Baudrillard, J. (1991). Simulacra and Science Fiction. Science-Fiction Studies, $\underline{18}$, 309-313.

Baudrillard, J. (1994). The Illusion of the End. Cambridge: Polity.

Bishop, M. (1983). In Pursuit of 'Ubik'. In M. H. Greenberg \& J. D. Olander (Eds.), Philip K. Dick: Criticism and Interpretation (pp. 137-147). New York: Taplinger.

Boje, D. M., Fitzgibbons, D. E., \& Steingard, D. S. (1996). Storytelling at Administrative Science Quarterly: Warding off the Postmodern Barbarians. In D. M. Boje, R. P. Gephart Jr., \& T. J. Thatchenkery (Eds.), Postmodern Management and Organization Theory (pp. 60-92). Thousand Oaks: Sage.

Bourdieu, P. (1992). Thinking About Limits. Theory, Culture \& Society, $\underline{9}$, 37-49.

Brown, D. (1997). Cybertrends: Chaos, Power and Accountability in the Information Age. London: Viking.

Burrell, G. (1992). Back to the Future: Time and Organization. In M. Reed \& M. Hughes (Eds.), Rethinking Organization: New Directions in Organization Theory and Analysis (pp. 165-183). Newbury Park/London: Sage.

Burrell, G. (1996). Normal Science, Paradigms, Metaphors, Discourses and Genealogies of Analysis. In S. R. Clegg, C. Hardy, \& W. R. Nord (Eds.), Handbook of Organization Studies (pp. 642-658). London: Sage.

Casey, C. (1995). Work, Self and Society After Industrialism. London: Routledge.

Chia, R. (1996a). The Problem of Reflexivity in Organizational Research: Towards a Postmodern Science of Organization. Organization, $\underline{3}$, 31-58.

Chia, R. (1996b). Teaching Paradigm Shifting in Management Education: University Business Schools and the Entrepreneurial Imagination. Journal of Management Studies, 33, 409-428.

Chia, R. (1997). Thirty Years On: From Organizational Structures to the Organization of Thought. Organization Studies, 18(4), 685-707. 
Cooper, R., \& Law, J. (1995). Organization: Distal and Proximal Views. Research in the Sociology of Organizations, 13 , 237-274.

Czarniawska, Barbara (1997). Narrating the Organization: Dramas of Institutional Identity. Chicago: University of Chicago Press.

Davis, M. S. (1986). That's Classic! The Phenomenology and Rhetoric of Successful Social Theories. Philosophy of Social Science, 16, 309-344.

Dick, P. K. (1953/1990). Breakfast at Twilight. In Second Variety, Volume 2 of the Collected Stories of Philip K. Dick (pp.267-284). London: Harper Collins.

Dick, P. K. (1953/1990). The Hanging Stranger. In The Father Thing, Volume 3 of the Collected Stories of Philip K. Dick (pp.28-43). London: Harper Collins.

Dick, P.K. (1962/1992). The Man in the High Castle. New York: Vintage.

Dick, P. K. (1964/1990). Martian Time Slip. London: VGSF

Dick, P. K. (1964/1991). The Three Stigmata of Palmer Eldritch. New York: Vintage

Dick, P. K. (1966/1975). Now Wait for Last Year. St.Albans: Granada

Dick, P. K. (1967/1990). Counter-Clock World. London: Grafton

Dick, P. K. (1969/1991). Ubik. New York: Vintage.

Dick, P. K. (1972/1995). The Android and the Human. In L. Sutin (Ed.), The Shifting Realities of Philip K. Dick: Selected Literary and Philosophical Writings (pp. 183210). New York: Vintage.

Dick, P. K. (1974/1996). Flow My Tears, The Policeman Said. London: Voyager

Dick, P. K. (1976/1995). Man, Android, and Machine. In L. Sutin (Ed.), The Shifting Realities of Philip K. Dick: Selected Literary and Philosophical Writings (pp. 211232). New York: Vintage.

Dick, P.K. (1977/1995). If You Find This World Bad, You Should See some of the Others. In L. Sutin (Ed.), The Shifting Realities of Philip K. Dick: Selected Literary and Philosophical Writings (pp. 233-258). New York: Vintage.

Dick, P. K. (1980/1995). Book Review of The Cybernetic Imagination in Science Fiction. In L. Sutin (Ed.), The Shifting Realities of Philip K. Dick: Selected Literary and Philosophical Writings (pp. 96-98). New York: Vintage.

Dick, P. K. (1981/1992). Valis. London: Grafton.

Dick, P. K. (1991). In Pursuit of Valis: Selections From the Exegesis. Novato (CA): Underwood-Miller. 
Disch, T. M. (1983). Toward the Transcendent: An Introduction to 'Solar Lottery' and Other Works. In M. H. Greenberg \& J. D. Olander (Eds.), Philip K. Dick: Criticism and Interpretation (pp. 13-25). New York: Taplinger.

Easterbrook, N. (1995). Dianoia/Paranoia: Dick's Double 'Impostor'. In S. J. Umland (Ed.), Philip K. Dick: Contemporary Critical Interpretations (pp. 19-41). Westport: Greenwood Press.

Easton, G., \& Araujo, L. (1997). Management Research and Literary Criticism. British Journal of Management, $\underline{8}$, 99-106.

Fournier, V, \& Grey, C. (2000). At the Critical Moment: Conditions and Prospects for Critical Management Studies. Human Relations, 53 (1), 7-32.

Gephart Jr., R. P., Thatchenkery, T. J., \& Boje, D. M. (1996). Conclusion: Restructuring Organizations for Future Survival. In D. M. Boje, R. P. Gephart Jr., \& T. J. Thatchenkery (Eds.), Postmodern Management and Organization Theory (pp. 358-364). Thousand Oaks: Sage.

Gergen, K. J. (1995). Global Organization: From Imperialism to Ethical Vision. Organization, 2, 519-532.

Gibson, W. (1984). Neuromancer. London: Victor Gollancz.

Giddens, A. (1990). The Consequences of Modernity. Cambridge: Polity.

Golden-Biddle, K., \& Locke, K. (1993). Appealing Work: An Investigation of How Ethnographic Texts Convince. Organization Science, 4(4), 595-616.

Hardy, C., \& Clegg, S. (1997). Relativity Without Relativism: Reflexivity in PostParadigm Organization Studies. British Journal of Management, $\underline{8}$, S5-S17.

Hassard, J., \& Holliday, R. (1998). Introduction. In J. Hassard \& R. Holliday (Eds.), Organization-Representation (pp. 1-15). London: Sage.

Hayles, N. K. (1999). How We Became Posthuman: Virtual Bodies in Cybernetics, Literature, and Informatics. Chicago: University of Chicago Press.

Hunter, J.M.F. (1985). Understanding Wittgenstein. Edinburgh: Edinburgh University Press.

Kallinikos, J. (1997). Classic Review: Science, Knowledge and Society: The Postmodern Condition Revisted. Organization, 4, 114-129.

Kilduff, M., \& Mehra, A. (1997). Postmodernism and Organizational Research. Academy of Management Review, 22, 453-481.

Lash, S., \& Urry, J. (1994). Economies of Signs and Space. London: Sage. 
Latour, B. (1988). The Politics of Explanation: An Alternative. In S. Woolgar (Ed.) Knowledge and Reflexivity: New Frontiers in the Sociology of Knowledge. (p.155176). London: Sage.

LeGuin, U. K. (1994). A Fisherman of the Inland Sea. New York: Harper Collins.

Lem, S. (1984). Microworlds: Writings on Science Fiction and Fantasy. London: Harcourt Brace Jovanovich.

Locke, K., \& Golden-Biddle, K. (1997). Constructing Opportunities for Contribution: Structuring Intertextual Coherence and 'Problematizing' in Organizational Studies. Academy of Management Journal, 40, 1023-1062.

March, J. G. (1995). The Future, Disposable Organizations and the Rigidities of Imagination. Organization, 2, 427-440.

McCloskey, D. N. (1994). Knowledge and Persuasion in Economics. Cambridge: Cambridge University Press.

Monk, R. (1990). Ludwig Wittgenstein: The Duty of Genius. London: Vintage.

Palmer, C. (1995). Philip K. Dick and the Nuclear Family. In S. J. Umland (Ed.), Philip K. Dick: Contemporary Critical Interpretations (pp. 61-79). Westport: Greenwood Press.

Parker, M. (2000). Organizational Culture and Identity. London: Sage.

Parker, M., \& Cooper, R. (1998). Cyborganization: Cinema as Nervous System. In J. Hassard \& R. Holliday (Eds.), Organization-Representation (pp. 201-228). London: Sage.

Phillips, N. (1995). Telling Organizational Tales: On the Role of Narrative Fiction in the Study of Organizations. Organization Studies, 16(4), 625-649.

Srinivas, N. (1999). Managers as Androids: Reading Moral Agency in Philip Dick. Organization, $\underline{6}$ (4), 609-624.

Starr, A. (1993). The God in the Trash. The New Republic, June (http://blake.oit.unc.edu/nr/articles/pkdick.htm)

Sutin, L. (1991). Divine Invasions: A Life of Philip K. Dick.. New York: Carol Publishing.

Sutin, L. (1995). Introduction. In L. Sutin (Ed.), The Shifting Realities of Philip K. Dick: Selected Literary and Philosophical Writings (pp. ix-xxix). New York: Pantheon.

Suvin, D. (1983). Artifice as refuge and World View: Philip K. Dick's Foci. In M. H. Greenberg \& J. D. Olander (Eds.), Philip K. Dick: Criticism and Interpretation (pp. 7395). New York: Taplinger. 
Turner, B. A. (1992). The Symbolic Understanding of Organizations. In M. Reed \& M. Hughes (Eds.), Rethinking Organization: New Directions in Organization Theory and Analysis (pp. 46-66). Newbury Park/London: Sage.

Vickers, G. (1995). The Art of Judgment: A Study of Policy Making (Centenary edition ed.). London: Sage.

Warrick, P. S. (1983). The Labyrinthian Process of the Artificial: Philip K. Dick's Androids and Mechanical Constructs. In M. H. Greenberg \& J. D. Olander (Eds.), Philip K. Dick: Criticism and Interpretation (pp. 189-214). New York: Taplinger.

Weiskopf, R. and H. Willmott (1997). Turning the Given into a Question: A Critical Discussion of Chia's Organizational Analysis as Deconstructive Practice. Electronic Journal of Radical Organization Theory, $\underline{3}$ (2)), (http://www.mngt.waikato.ac.nz/ejrot)

Welchman, A. (1997). Funking up the Cyborgs. Theory, Culture \& Society, 14, 155162.

Williams, P. (1986). Only Apparently Real: The World of Philip K Dick. New York: Arbor House.

Zald, M. N. (1996). More Fragmentation? Unfinished Business in Linking the Social Sciences and the Humanities. Administrative Science Quarterly, 41, 251-261.

\section{NOTES}

${ }^{1}$ Throughout the text I will refer to the date of the original writing and then that of my particular edition.

${ }^{2}$ Dick was a guest of honour at the September 1977 SF festival at Metz - probably one of the first times he received such massive recognition - and would have returned there in 1982 (Dick, unfortunately, died on March 2, 1982).

3 'Cyberspace' was, of course, a concept first coined in a SF novel. In Neuromancer (1984), William Gibson produced a concept that was at once recognisable, and made possible the cognition of a whole new arena of the life world that had already been constructed unconsciously by an array of convergent information-processing technologies (Welchman, 1997).

${ }^{4}$ Not that this is explicitly stated. Sometimes adventurous communicational practices are encouraged in editorial guidelines but then reviewers comments come back: 'what are the key points you want to get across, present a clear argument, I like your idea but...' which forces us to repudiate certain values such as paradox, ambiguity, inconsistency. Thinking of our careers of course we comply. And yet, it has been suggested (in a very unambiguous way of course) that if language attempts to be too precise, then meaningful statements about organisational functioning appear unlikely; insightful models will tend to be somewhat ambiguous, vague, and imprecise (Astley \& Zammuto, 1992; Davis, 1986).

${ }^{5}$ From a letter to Engelmann written in 1917 and reproduced in Monk's (1992, p.151) biography. 
6 'In 1953 I started writing the worst trashy stuff you ever read, and none of that stuff is in print. In 1953 I sold twenty-seven stories, and twenty-six of the twenty-seven were rotten, worthless pieces of fiction (an interview quote from The Mainstream that Through the Ghetto Flows: An Interview with Philip K. Dick, http://www.missouri.edu/ moreview/interviews/dick.htm)

${ }^{7}$ For example, Joe Chip's multiplex FM tuner regresses into a cylinder phonograph playing a shouted recitation of the Lord's prayer. The regression of forms is a theme used by Dick to great effect in several other novels (e.g., in Counter Clock World).

${ }^{8}$ In the early 1960s Dick popped amphetamines like crazy and channeled the released energy into an astonishingly large creative output (during 1963-1964 he wrote ten novels in just under two years, many of which are now acknowledged classics). ${ }^{9}$ This suggestion is far from revolutionary. Hunter (1985) describes in some detail how Wittgenstein seemed to make some point of avoiding explaining what he wished to say: 'He prescribed work programmes, but did not explain how to carry them out, or in what way he thought their results would be relevant; he asked questions but did not answer them; posed questions he thought ought not be asked, without saying so until much later, and then only indirectly; asked apparently rhetorical questions when it turned out he thought they called for careful answering... (p. viii)' Latour (1988) suggests that 'The ideal of an explanation is not to be reached, not only because it is unreachable, but because it is not a desirable goal anyway (p.164).' Providing an explanation is working at empire building.

${ }^{10}$ Srinivas (1999) reminds us of one of Dick's characters in The Man in the High Castle who notes 'the power of fiction, even cheap popular fiction to evoke (p.125)'. Reflecting on that novel, Dick (1977/1995) later expressed his disinterest in explanation: "When he [Mr. Tagomi] looked up, he was in another universe. I didn't explain how or why this happened because I don't know, and I would defy anyone, writer, reader, or critic, to give a so-called “explanation” (Dick, 1977/1995, p.237).' 